\title{
To the study of gnaphosid spiders (Aranei: Gnaphosidae) of Western Azerbaijan with suggestion of two new synonyms
}

\section{K изучению пауков гнафозид (Aranei: Gnaphosidae) Западного Азербайджана с предложкением двух новых синонимов}

\author{
Shafa I. Khasayeva, Elchin F. Huseynov \\ Шафа И. Хасаева, Эмьчин Ф. Гусейнов
}

\begin{abstract}
Institute of Zoology, Azerbaijan National Academy of Sciences, block 504, passage 1128, Baku Az-1073, Azerbaijan. E-mail: Shafa_Xasayeva@mail.ru, apsheron@list.ru

Институт Зоологии, Национальная Академия наук Азербайджана, квартал 504, проезд 1128, Баку Аз-1073, Азербайджан.
\end{abstract}

KEY WORDS: Araneae, Caucasus, Ganja-Gazakh Region, new record, new synonym.

КЛЮЧЕВЫЕ СЛОВА:Araneae, пауки, Кавказ, новое указание, новый синоним.

\begin{abstract}
Twenty five species of ground spiders were found in Ganja-Gazakh Region of Azerbaijan, eighteen (18) of which are new records for the fauna of the studied area. Of these two species, Drassyllus villicus (Thorell, 1875) and Zelotes aeneus (Simon, 1878) are reported for the first time for the faunas of Caucasus and Azerbaijan respectively. Synonymy of Talanites aculeatus Charitonov, 1946 under Berinda amabilis Roewer, 1928 is rejected. Instead, a new synonymy Anagraphis pallens Simon, 1893 = Talanites aculeatus Charitonov, 1946 syn.n. is proposed. Prosthesima semibadia L. Koch, 1878 (= Zelotes semibadius (L. Koch, 1878)), syn.n is synonymized with Trachyzelotes jaxartensis (Kroneberg, 1875).
\end{abstract}

РЕЗЮМЕ. Двадцать пять видов пауков семейства Gnaphosidae обнаружены на территории Гянджа-Казахского региона Азербайджана, из которых 18 видов впервые указываются для фауны исследуемого региона. Два вида Drassyllus villicus (Thorell, 1875) и Zelotes aeneus (Simon, 1878) являются новыми для фаун Кавказа и Азербайджана соответственно. Синонимия Talanites aculeatus Charitonov, 1946 с Berinda amabilis Roewer, 1928 отвергается. Вместо этого предлагается новая синонимия Anagraphis pallens Simon, $1893=$ Talanites aculeatus Charitonov, 1946 syn.n. Также вид Prosthesima semibadia L. Koch, 1878 (= Zelotes semibadius (L. Koch, 1878)), syn.n синонимизирован с Trachyzelotes jaxartensis (Kroneberg, 1875).

\section{Introduction}

Among the Republics of the former Soviet Union Azerbaijan is relatively well studied in respect to spider fauna. According to the recent catalogue by Mikhailov [2013] it comprises 663 species from 42 families. Gnaphosidae is one of the most species rich families in Azerbaijan (with over 70 properly identified species) with only Salticidae (over 80 species) and Linyphiidae (over 90 species) being more diverse [Mikhailov, 2013]. However, different regions of Azerbaijan are studied unevenly in respect to gnaphosids (as well as other spider families). The areas that support the high number of gnaphosid species are Absheron Peninsula (38 species) [Dunin, 1984; Guseinov, 1999] Nakhchyvan (29) [Marusik et al., 2005], ShekiZagatala area (28) [Dunin, 1989; Huseynov et al., 2003], Lenkoran area (27) [Guseinov, 1999], and Gobustan (27) [Alieyva, 2010; Nuruyeva, Guseinov, $2011]$.

This paper concerning gnaphosids of Ganja-Gazakh region of Azerbaian, presents some results of our investigation of this poorly studied area. Despite the large area, little is known about araneofauna of this territory compared to some other regions of Azerbaijan (see above mentioned). Up to date, about 80 species of spiders from 21 families were recorded from GanjaGazakh region, 13 of which belong to Gnaphosidae [Khasayeva, 2014]. All these records were provided by Ovtsharenko, who firstly reported 12 gnaphosid species from genera Callilepis Westring, 1874, Drassyllus Chamberlin, 1922, Gnaphosa Latreille, 1804, Haplodrassus Chamberlin, 1922, Nomisia Dalmas, 1921, Talanites Simon, 1893, Trachyzelotes Lohmander, 1944, Zelotes Gistel, 1848 [Ovtsharenko, 1982] and then added one more species Gnaphosa steppica Ovtsharenko, Platnick et Song, 1992 [Ovtsharenko et al., 1992]. Later, Tuneva \& Esyunin [2003] have concluded that the last record refers to a new species Gnaphosa azerbaidzhanica Tuneva et Esyunin, 2003.

\section{Material and Methods}

Most of material treated herein was collected by authors during short-term trips to different points in 
Agstafa, Gazakh, Tovuz, Shamkir, Gyoy-gyol, Dashkesan, Gedabey and Goranboy districts of Ganja-gazakh Region in 2014-2016. Specimens were collected by litter sifting, pitfall trapping and hand picking. Collected spiders were preserved in $70 \%$ ethanol and brought back to the laboratory, where they were identified under a NÝKON SMZ 1270 stereomicroscope. Digital images of the palps and epigynes were taken with a digital camera SONY DSC - P8. The studied material is deposited in the collection of Institute of Zoology, Azerbaijan National Academy of Sciences, Baku. The species new to the fauna of Ganja-Gazakh Region are marked with one asterisk "**", species new to Azerbaijan are marked with two asterisks "**", and species new to the fauna of Caucasus are indicated by three asterisks “***”. Collector's names are abbreviated as follows: EH - E.F. Huseynov; SKh - S.I. Khasaeva.

\section{Species survey}

\section{Anagraphis Simon, 1893}

Anagraphis pallens Simon, 1893

Figs 1-8.

Anagraphis pallens Levy, 1999: 216, f. 1-7 (О'T); Chatzaki et

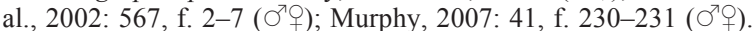

Talanites aculeatus Charitonov, 1946: 26, f. $43\left(0^{7}\right)$, syn.n.

MATERIAL. $20^{7} \sigma^{7}, 1$, Goranboy Dist., 13.05 .15 (EH).

DISTRIBUTION. Mediterranean to Cenral Asia [Levy, 1999; Chatzaki et al., 2002; Mikhailov, 2013, see below]. Record from South Africa is apparently erroneous [Platnick, Baehr, 2006].

REMARK. Record of $A$. pallens could be formally considered as a new for Azerbaijan and the Caucasus as a whole. However, this species has been repeatedly reported from different parts of Azerbaijan under the name Talanites aculeatus Charitonov, 1946 [Ovtsharenko, 1982; Dunin, 1984; Guseinov, 1999]. Recently Chatzaki et al. [2002] have synonymized $T$. aculeatus with Berinda amabilis Roewer, 1928. Yet, by palpal conformation $T$. aculeatus has nothing in common with $B$. amabilis (see fig. 43 [Charitonov, 1946] vs. fig. 12-13 [Chatzaki et al., 2002]), while, on the other hand, it is very similar to the type-species of the genus Anagraphis Simon, 1893, A. pallens (cf. fig. 3 [Levy, 1999]). According to description by Charitonov [1946], T. aculeatus also differs significantly from $B$. amabilis by coloration, absence of scutum in males, leg spination and chelicerae dentition and lacking a preening comb on third and fourth metatarsi. Chelicerae of B. amabilis bear 2 anterior and 3 posterior teeth [Chatzaki et al., 2002], while $T$. aculeatus, in contrast, has 3 anterior and 2 posterior teeth on chelicerae [Charitonov, 1946]. The latter formula is characteristic of A. pallens [Levy, 1999]. Taking into account the above mentioned, we reject synonymy of $T$. aculeatus with $B$. amabilis and, instead, propose a new synonymy Talanites aculeatus Charitonov, 1946, syn.n. = Anagraphis pallens Simon, 1893.

\section{Aphantaulax Simon, 1878}

Aphantaulax trifasciata (O. Pickard-Cambridge, 1872)* (SKh).

MATERIAL. 1 \%, Gazakh Dist., Khanliglar Vil., 24.08.2015

DISTRIBUTION. From Europe to Cental Asia [Mikhailov, 2013, Helsdingen, 2014].

\section{Drassodes Westring, 1851}

Drassodes lapidosus (Walckenaer, 1802)*

MATERIAL. 1 ㅇ, Agstafa Dist., Poylu Vil., 19.05.2012 (N.Y. Snegovaya); 1 \% , Goranboy Dist., env. of Goranboy Town, 14.05.2015 (EH); 3 우, Gedabey Dist., Novo-saratovka Vil.,

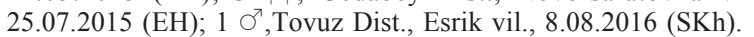

DISTRIBUTION. West Palearctic [Mikhailov, 2013; Helsdingen, 2014].

Drassodes pubescens (Thorell, 1856)*

MATERIAL. $1 \sigma^{7}, 1$, Gedabey Dist., Novo-saratovka Vil., 25.07.2015 (EH); 1 + , Dashkesan Dist., Khoshbulag Vil., 26.06.2016 (SKh).

DISTRIBUTION. Trans-palearctic range [Mikhailov, 2013; Helsdingen, 2014].

\section{Drassyllus Chamberlin, 1922}

Drassyllus praeficus L. Koch, 1866*

MATERIAL: $4 \mathrm{O}^{7} \sigma^{7}$, env. of Agstafa Town, 29.04-6.06.2014 (SKh); 1 + , Tovuz Dist., Esrik-Jirdakhan Vil., 8.08.2016 (SKh).

DISTRIBUTION. West Palearctic [Mikhailov, 2013; Helsdingen, 2014].

Drassyllus villicus (Thorell, 1875)***

MATERIAL. $1 \mathrm{O}^{7}$, Agstafa Dist., env. of Agstafa Town, 29.04.2014 (SKh). 2014].

DISTRIBUTION. European species [Helsdingen,

REMARK. The new record from Azerbaijan is easternmost range of the species.

\section{Gnaphosa Latreille, 1804}

Gnaphosa leporina (L. Koch, 1866)*

MATERIAL. $1 \sigma^{7}$, Agstafa Dist., Ashagy Kesemen Vil., 14.12.2013 (SKh); 1 o , 3 우, env. of Agstafa Town, 29.046.06.2014 (SKh).

DISTRIBUTION. West Palearctic [Mikhailov, 2013; Helsdingen, 2014].

Gnaphosa modestior Kulczyński, 1897*

MATERIAL. $1 \sigma^{7}, 1$, Dashkesan Dist., Khoshbulag Vil., 26.06. 2016 (SKh).

DISTRIBUTION. West Palearctic [Komnenov et al., 2016]

Gnaphosa taurica Thorell, 1875*

MAERIAL. 1 \%, Dashkesan Dist., Khoshbulag Vil., 26.06. 2016 (SKh).

DISTRIBUTION. East Europe to West Siberia [Kovblyuk, 2005; Mikhailov, 2013]. 


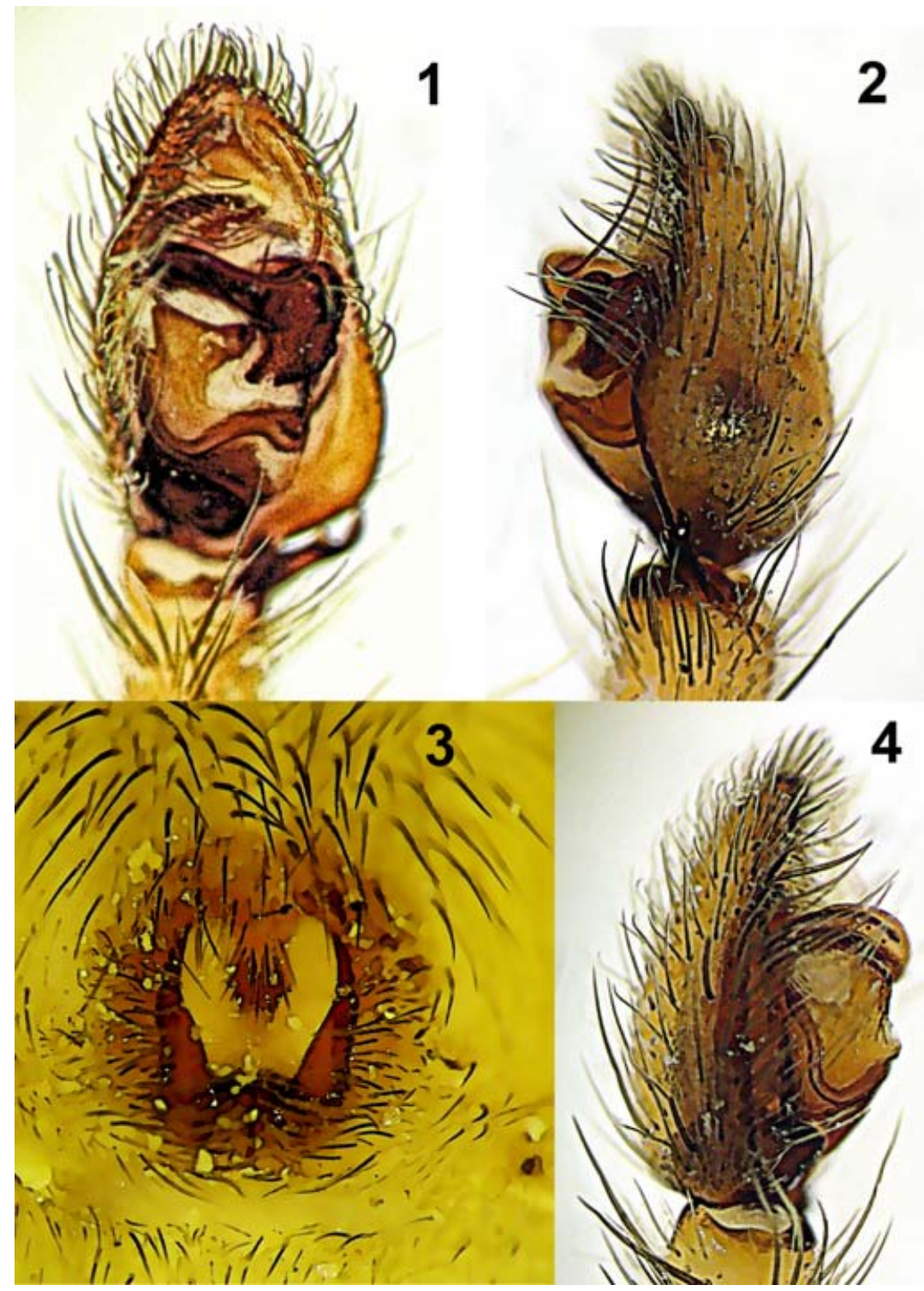

Figs 1-4. Anagraphis pallens from Goranboy: 1, 2, 4 - male palp, ventral, retrolateral and prolateral; 3 - epigyne.

Рис. 1-4. Anagraphis pallens из Гёранбоя: 1, 2,4 - пальпа самца, вентрально, ретролатерально и пролатерально; 3 - эпигина.

\section{Haplodrassus Chamberlin, 1922}

Haplodrassus dalmatensis (L. Koch, 1866)*

MATERIAL. 7 O $^{7} 0^{7}$, env. of Agstafa Town, 29.04.2014 (SKh); 1 , , Shamkir Dist., Seyfeli Vil., 24.08.2015 (SKh).

DISTRIBUTION. West Palearctic [Mikhailov, 2013; Helsdingen, 2014].

Haplodrassus signifer (C.L. Koch, 1839)

MATERIAL. 1 O', Tovuz Dist., Khatýnly Vil., 11.05.2014 (SKh); 1 \%, Gazakh Dist., Khanliglar Vil., 19.05.2016 (SKh).

DISTRIBUTION. Circum-Holarctic range [Marusik et al., 2000].

\section{Micaria Westring, 1851}

Micaria albovittata (Lucas, 1846)*

MATERIAL. 1 +, Gedabey Dist., Saratovka Vil., 25.07.2015
(EH); 1 ○ึ, 1 क, Dashkesan Dist., Khoshbulag Vil., 26.06.2016 (SKh).

DISTRIBUTION. Palearctic species [Chatzaki et al., 2002; Mikhailov, 2013].

Micaria rossica Thorell, 1875*

MATERIAL. 2 우, Agstafa Dist., env. of Agstafa Town, 29.04.2014 (SKh).

DISTRIBUTION. Trans-Palaearctic - West-Nearctic range [Kovblyuk, Nadolny, 2008].

\section{Nomisia Dalmas, 1921}

Nomisia conigera (Spassky, 1941)

MATERIAL. 1 +, Goranboy Dist., env. of Goranboy Town, 12.05.2015 (EH)

DISTRIBUTION. Turkey, Azerbaijan, Central Asia [Chatzaki, 2010; Mikhailov, 2013]. 


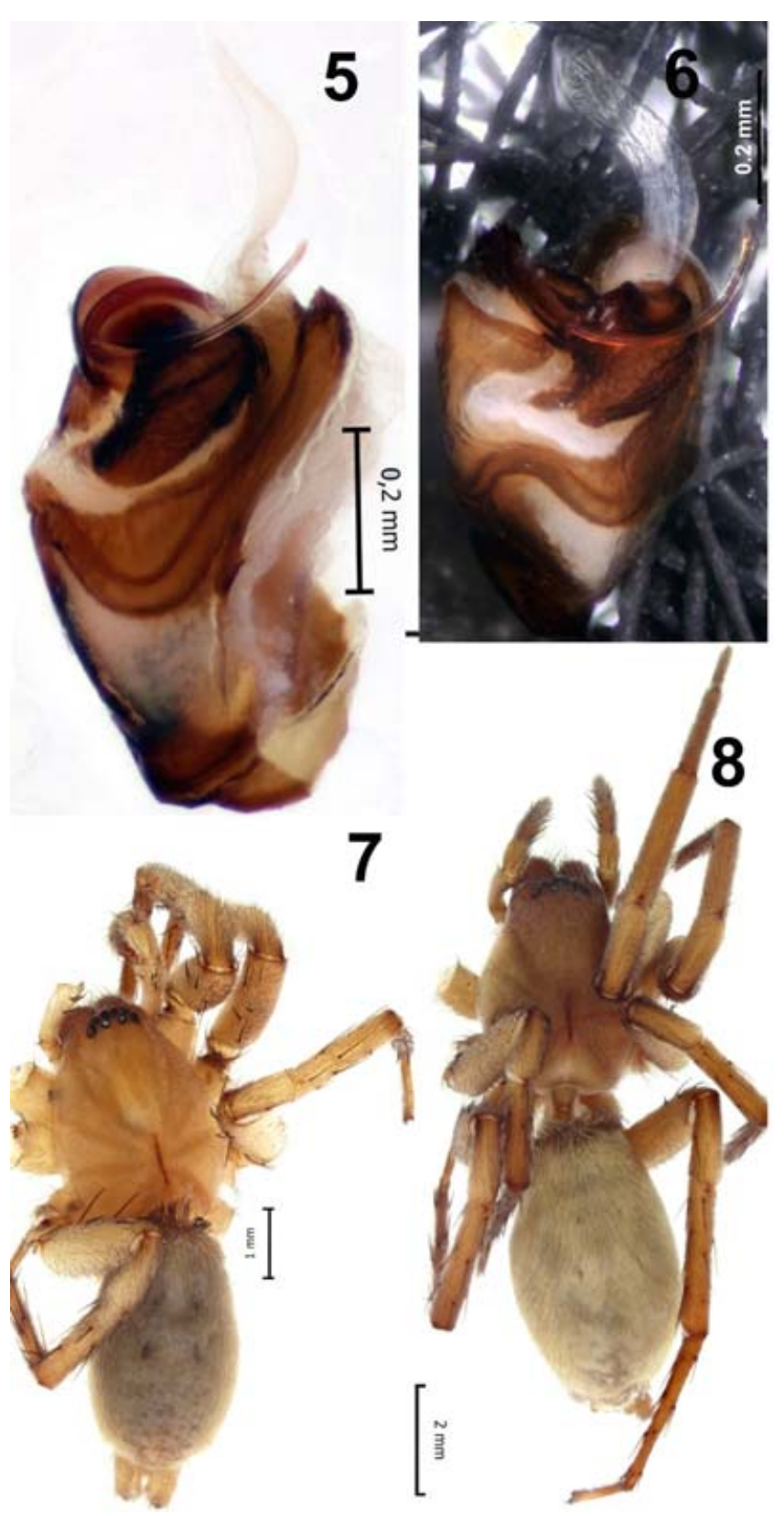

Figs 5-8. Anagraphis pallens from Absheron: 5, 6- male palp, ventral; 7 (male), 8 (female) - general appearence. Рис. 5-8. Anagraphis pallens из Апшерона: 5, 6 - пальпа самца вентрально; 7 (самец), 8 (самка) - внешний вид.

Nomisia exornata (C.L. Koch, 1839)

MATERIAL. $1 \sigma^{7}$, Shamkir Dist., Seyfeli Vil., 24.08.2015 (SKh); 3 O $^{7} \sigma^{7}$, Tovuz Dist., Esrik-Jirdakhan Vil., 8.08.2016 (SKh). DISTRIBUTION. Europe to Central Asia [Chatzaki, 2010; Mikhailov, 2013; Helsdingen, 2014].

Nomisia ripariensis (O. Pickard-Cambridge, 1872)* MATERIAL. $1 \bigcirc^{7}$, Gazakh Dist., Khanliglar Vil., 24.08.2015 (SKh)

DISTRIBUTION. East Mediterranean to Caucasus [Chatzaki, 2010; Mikhailov, 2013].

\section{Trachyzelotes Lohmander, 1944}

Trachyzelotes barbatus (L. Koch, 1866)*

MATERIAL. 1 +, Tovuz Dist., Esrik-Jirdakhan Vil., 2016 (SKh).

DISTRIBUTION. From West Mediterranean to Central Asia, introduced to USA [Kovblyuk, Tuneva, 2009].

Trachyzelotes jaxartensis (Kroneberg, 1875) *

Figs 9-12.

Melanophora jaxartensis Kroneberg, 1875: 23, pl. 2, f. 1 (†); 


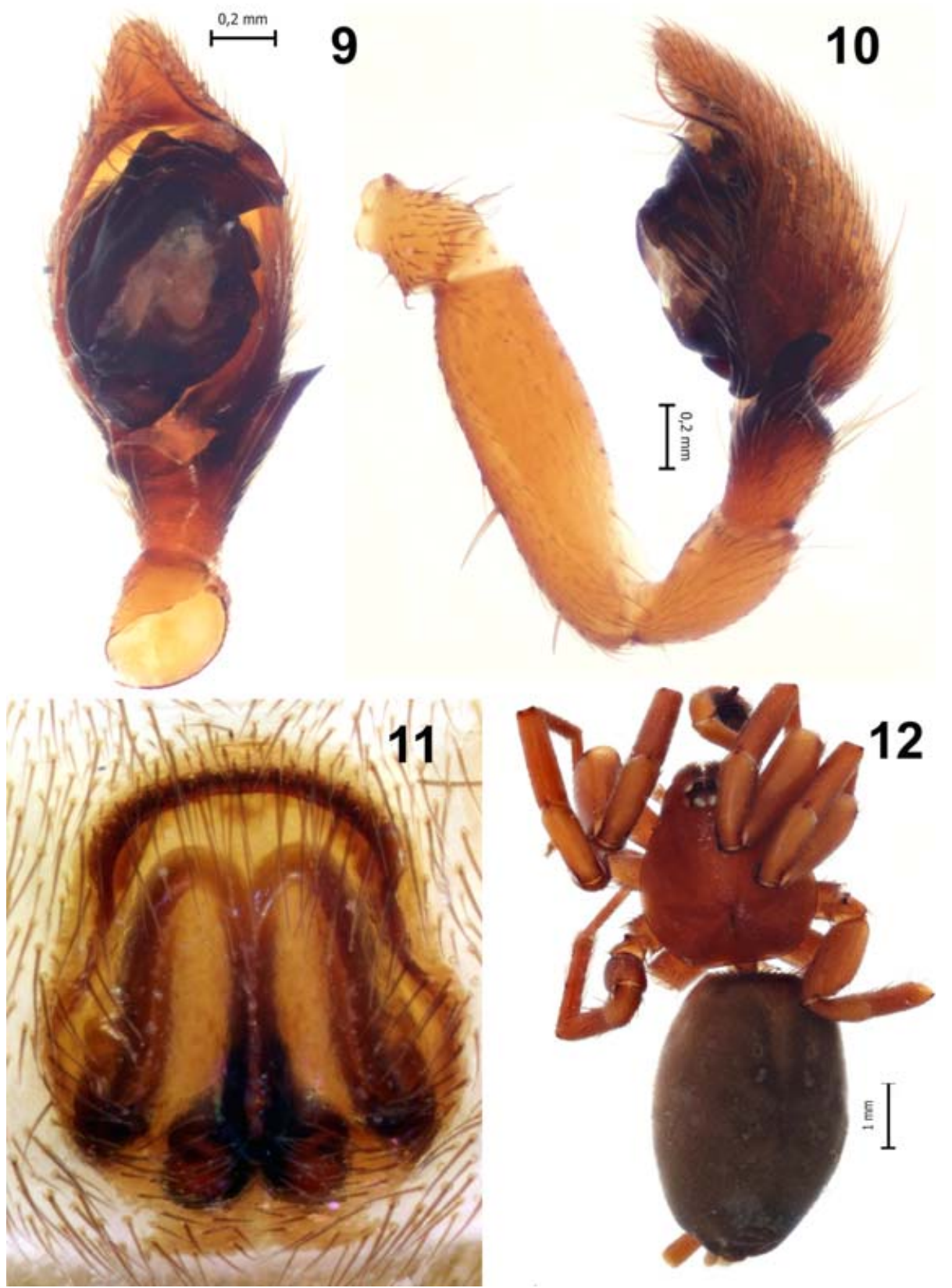

Figs 9-12. Trachyzelotes jaxartensis from Goranboy: 9, 10 - male palp, ventral and retrolateral; 11 - epigynum; 12 - male, general appearance.

Рис. 9-12. Trachyzelotes jaxartensis из Гёранбоя: 9, 10 — пальпа самца вентрально и ретролатерально; 11 - эпигина; 12 внешний вид самца.

Trachyzelotes jaxartensis: Platnick, Murphy, 1984: 10, f. 19-

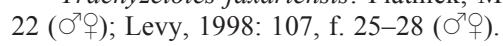

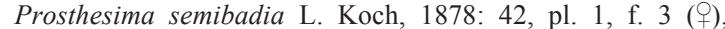
syn.n.

MATERIAL. $1 \bigcirc^{\top}, 1$ + , Goranboy Dist., env. Goranboy Town, 15.05.2015 (EH);

DISTRIBUTION. Natilevy from West Palearctic, from West Mediterranean to Central Asia, introduced worldwide [Platnick, Murphy, 1984].

REMARKS. New record for Gyanja-Gazakh Region. L. Koch [1878] described Prosthesima semiba- dia (= Zelotes semibadius (L. Koch, 1878)) on the basis of a single female "von Baku". Since its original description, there have been no further records concerning the taxonomy and distribution of the species. It is remarkable, however, that Koch described the presence of dense stiff setae on anterior surface of chelicerae of $Z$. semibadius, which is distinguishing character of the recent genus Trachyzelotes Lohmander, 1944 [Platnick, Murphy, 1984]. Moreover, he pointed out the similarity of a new species to Prostesima barbata 
Table 1. The species and genera diversity of gnaphosid spiders in different regions of Azerbaijan. Таблица 1. Видовое и родовое разнообразие пауков-гнафозид в различных регионах Азербайджана.

\begin{tabular}{|l|c|c|c|l|}
\hline \multicolumn{1}{|c|}{ Region } & Area km2 & $\begin{array}{c}\text { Number of } \\
\text { species }\end{array}$ & $\begin{array}{c}\text { Number of } \\
\text { genera }\end{array}$ & \multicolumn{1}{|c|}{ Literature } \\
\hline Absheron Peninsula & 2110 & 38 & 20 & Dunin, 1984; Guseinov, 1999 \\
\hline Nakhchivan AR & 5500 & 30 & 14 & Marusik et al., 2005 \\
\hline Sheki-Zagatala Area & 8840 & 28 & 13 & $\begin{array}{l}\text { Dunin, 1989; Huseynov et al., } \\
\text { 2003 }\end{array}$ \\
\hline Lenkoran Area & 6070 & 28 & 17 & Guseinov, 1999 \\
\hline Gobusan Region & 5550 & 27 & 16 & $\begin{array}{l}\text { Alieyva, 2010; Nuruyeva, } \\
\text { Guseinov, 2011 }\end{array}$ \\
\hline Ganja-Gazakh Region & 12300 & 31 & 12 & Present paper \\
\hline
\end{tabular}

(= Trachyzelotes barbatus (L. Koch, 1866)). Thus, in our opinion, it is without doubt, that Z. semibadius belongs to the genus Trachyzelotes. Four species of Trachyzelotes have been recorded from Absheron Peninsula (where Baku City is located), namely, T. barbatus (L. Koch, 1866), T. jaxartensis (Kroneberg, 1875), T. lyonetti (Audouin, 1826) and T. malkini Platnick et Murphy, 1984 [Ovtsharenko, 1982; Dunin, 1984; Guseinov, Rubtsova, 2001]. As it is evident from Koch's own text, $T$. barbatus is certainly a different species. The same is apparently true for T. malkini which is closely related to T. barbatus and could be easily confused with the later species by genital organs [Kovblyuk, 2004]. Of the remaining species only epigyne of $T$. jaxartensis resembles that of $Z$. semibadius (cf. fig. 27 [Levy, 1998] vs. Taf.1, fig.3 [Koch, 1878]), whereas $T$. lyonetti has very different shape of epigyne (cf. fig. 21 [Levy, 1998], fig. 29 [Chatzaki et al., 2003]). Taking into account the above mentioned we consider Prosthesima semibadia L. Koch, 1878 (= Zelotes semibadius (L. Koch, 1878)), syn.n. as a junior synonym of T. jaxartensis (Kroneberg, 1875).

Trachyzelotes malkini Platnick et Murphy, 1984*

MATERIAL. 2 oㅇ, Agstafa Dist., Ashagy Kesemen Vil., 14.12.2014 (SKh); 3 O $^{7} \sigma^{7}$, 2 우, env. of Agstafa Town, 29.046.06.2014 (SKh); $1 \mathrm{O}^{\top}$, Gazakh Dist., Khanliglar Vil., 19.05.2016 (SKh).

DISTRIBUTION. East Mediterranean to Kazakhstan [Platnick, Murhy, 1984; Mikhailov, 2013].

Trachyzelotes pedestris (C.L. Koch, 1837)

MATERIAL. 2 우, Agstafa Dist., Ashagy Kesemen Vil., 9.04.2014 (SKh); 1 \%, env. of Agstafa Town, 6.06.2014 (SKh); 1 +, Gyoy-gyol Dist., Hajikend Vil., 22.08.2015 (SKh).

DISTRIBUTION. West Palearctic [Levy, 1998; Mikhailov, 2013; Helsdingen, 2014; Zamani et al., 2016].

\section{Urozelotes Mello-Leitao, 1938}

Urozelotes rusticus (L. Koch, 1872)*

MATERIAL. $1 \bigcirc^{7}$, Agstafa Dist., Ashagy Kesemen Vil., 14.12.2014 (SKh).

DISTRIBUTION. Virtualy Cosmopolitan species, distributed from Mediterranean to West Siberia and Japan, and also Canada, USA, Hawaii, South America up to Chile, India, Borneo, Zimbabwe and South Africa [Platnick, Murhy, 1984, Mikhailov, 2013].

\section{Zelotes Gistel, 1848}

Zelotes aeneus (Simon, 1878)**

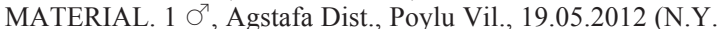
Snegovaya) 2014].

DISTRIBUTION. European species [Helsdingen,

REMARK. Previously this species was recorded from North Caucasus [Mikhailov, Mikhailova, 2002], but recently this record is considered as doubtful [Mikhailov, 2013]. But, we consider our record only as a new for Azerbaijan, not for the whole Caucasus.

Zelotes longipes (L. Koch, 1866)

MATERIAL. 1 9, Tovuz Dist., Khatýnlý Vil., 11.05.2014 (SKh); 7 +⿱, env. of Agstafa Town, 9.04.2014 (SKh); 2 + bey Dist., Novo-ivanovka Vil., 7.10.2015 (EH); 1 \%, Dashkesan Dist., Khoshbulag Vil., 26.06.2016 (SKh).

DISTRIBUTION. Trans-Palearctic range [Mikhailov, 2013; Helsdingen, 2014].

Zelotes petrensis (C.L. Koch, 1839)

MATERIAL. 4 오, Gegabey Dist., Novo-saratovka Vil., 6.10.2015 (EH).

DISTRIBUTION. European-Siberian species [Mikhailov, 2013; Helsdingen, 2014].

Zelotes subterraneus (C.L. Koch, 1833)*

MATERIAL. $10^{7}$, Agstafa Dist., Poylu Vil., 21.05.2012 (N.Y. Snegovaya); 1 , Gedabey Dist., Novo-ivanovka Vil., 25.07.2015 (EH).

DISTRIBUTION. West-Palearctic range [Kovblyuk, 2006].

\section{Discussion}

In result of our investigation 25 species of gnaphosid species belonging to 11 genera were found in Ganja-Gazakh region. Of these 18 species are recorded for the first time for the fauna of the studied area, including one new species for the Azerbaijan and one new record for entire Caucasus. Thereby, together with literature data, at present time, the araneofauna of Ganja-Gazakh region comprises 31 species of gnaphosids 
from 12 genera. This is comparable with gnaphosid diversity in other relatively well studied regions of Azerbaijan (Table 1). However, it is obvious that this figure does not reflect the real diversity of Gnahosidae of this region. It becomes evident if compare it with data from Absheron Peninsula, which is the only actually thoroughly studied area in Azerbaijan in respect to araneofauna. Despite the territory of Absheron is much smaller than areas of other regions, considerably more gnaphosid species were recorded from this area (Table 1).

ACKNOWLEDGEMENTS. We are very grateful to Dr. Yuri M. Marusik (Magadan, Russia) and Dr. Nataly Yu. Snegovaya for taking the photographs of copulatory organs of Anagraphis pallens and Trachyzelotes jaxartensis.

\section{References}

Alieva T.V. 2010. [To the study of spider fauna (Arachnida: Aranei) of Gobustan Reserve of Azerbaijan] // Caucasian Entomological Bulletin. Vol.6. No.2. P.133-142 [in Russian, with English summary].

Charitonov D.E. 1946. [New forms of spiders of the USSR] // Izvestija Estedvenno-Nauchnogo Instituta pri Molotovskom Gosudarstvennom Universitete. Vol.12. P.19-32 [in Russian, with English summary].

Chatzaki M. 2010. A revision of the genus Nomisia in Greece and neighboring regions with the description of two new species // Zootaxa. Vol.2501. P.1-22.

Chatzaki M., Thaler K., Mylonas M. 2002. Ground spiders (Gnaphosidae; Araneae) of Crete (Greece). Taxonomy and distribution. I // Revue suisse de Zoologie. T.109. Fasc.3. P.559-601.

Chatzaki M., Thaler K., Mylonas M. 2003. Ground spiders (Gnaphosidae; Araneae) from Crete and adjacent areas of Greece. Taxonomy and distribution. III. Zelotes and allied genera // Revue suisse de Zoologie. T.110. Fasc.1. P.45-89.

Dunin P.M. 1984. [Fauna and ecology of spiders (Aranei) of the Apsheron Peninsula (Azerbaijan SSR)] // Utotchkin A.S. et al. (eds.). Fauna i ekologiya paukoobraznykh. Perm. P.45-60 [in Russian].

Dunin P.M. 1989. [Fauna and altitudinal distribution of spiders (Arachnida, Aranei) of the Azerbaijan part of south sloping of the Caucasus Major] // Lange A.B. (ed.). Fauna i ekologiya paukov i skorpionov. Moscow: Nauka. P.31-39 [in Russian].

Guseinov E.F. 1999. [Spiders of Lenkoran Nature Region and Absheron Peninsula in Azerbaijan]. Authoreferate of $\mathrm{PhD}$ thesis. Baku. 29 pp. [in Russian, with Azerbaijani and English summaries].

Guseinov E.F., Rubtsova L.Ye. 2001. [New spiders species (Arachnida, Araneae) for the fauna of Azerbaijan] // XX esrin sonunda heyvanlar aleminin oyrenilmesi ve qorunmasý". Akademik M.E. Musayevin anadan olmasýnýn 80 illiyine hesr olunmup elmi konfransýn materiallarý. Baký: Elm. P.236-239 [in Russian, with English summary].

Helsdingen P.J.van.2014. Araneae // Fauna Europaea. Database European spiders and their distribution-Taxonomy-Version 2014.2 http://www.european-arachnology.org/reports/fauna. shtml

Huseynov E.F. Aliyev H.E., Sneqovaya N.Y. 2003. [To the knowledge of the spider fauna (Arachnida, Araneae) of Ýsmaýlly Reserve] // Azerbaycan Zooloqlar cemiyyYti, I Qurultayýn materiallarý, Baký. P.191-195 [in Azerbaijani, with English summary].

Khasayeva Sh.I. 2014. [To the study of spider fauna (Arachnida, Araneae) of Gaynja-Gazakh Region] // Gendzh alimlerin eserleri. Baku. No.9. P.125-127 [in Azerbaijani].
Koch L. 1878. Kaukasische Arachnoiden // Schneider O. (Hrsg.) Naturwissenschaftliche Beiträge zur Kenntniss der Kaukasusländer. Dresden. Bd.3. S.36-71.

Komnenov M., Pitta E., Zografou K., Chatzaki M. 2016. Discovering the still unexplored arachnofauna of the National Park of Dadia-Lefkimi-Soufli, NE Greece: a taxonomic review with description of new species // Zootaxa. Vol.4096. No.1. P.1-66.

Kovblyuk M.M. 2004. The spider genus Trachyzelotes Lohmander, 1944 in the Crimea, south Ukraine (Araneae: Gnaphosidae) // Logunov D.V., Penney D. (eds.) European Arachnology 2003 (Proceedings of the 21st European Colloquium of Arachnology, St.-Petersburg, 4-9 August 2003). Arthropoda Selecta, Special Issue 1. P.139-146.

Kovblyuk M.M. 2005. The spider genus Gnaphosa Latreille, 1804 in the Crimea (Aranei: Gnaphosidae) // Arthropoda Selecta. Vol.14. No.2. P.133-152.

Kovblyuk M.M. 2006. [Zelotes kukushkini sp. n. (Aranei, Gnaphosidae) and close related species from Palaearctic] // Vesnik Zoologii. Vol.40. No. P.205-217 [in Russian, with English summary].

Kovblyuk M.M., Nadolny A.A. 2008. The spider genus Micaria Westring, 1851 in the Crimea (Aranei: Gnaphosidae) // Arthropoda Selecta. Vol.16 (for 2007). No.4. P.215-236.

Kovblyuk M.M., Tuneva T.K. 2009. Three interesting species of Gnaphosidae from Crimea (Arachnida: Aranei) // Arthropoda Selecta. Vol.17 (for 2008). No.3-4. P.157-164.

Kroneberg A. 1875. [A journey to Turkestan by A.P. Fedchenko. Spiders, Araneae] // Izvestiya obshchesttva lyubiteley estesvoispytaniya, antropologii i etnograhii. Vol.19. P.1-58 [in Russian].

Levy G. 1998. The ground-spider genera Setaphis, Trachyzelotes, Zelotes, and Drassyllus (Araneae: Gnaphosidae) in Israel // Israel Journal of Zoology. Vol.44. P.93-158.

Levy G. 1999. Spiders of the genera Anagraphis and Talanites (Araneae, Gnaphosidae) from Israel // Israel Journal of Zoology. Vol.45. P.215-225.

Marusik Y.M., Guseinov E.F., Aliev H.A. 2005. Spiders (Arachnida: Aranei) of Azerbaijan 4. Fauna of Naxçivan // Arthropoda Selecta. Vol.13 (for 2004). No.3. P.135-149.

Marusik Y.M., Logunov D.V., Koponen S. 2000. Spiders of Tuva, south Siberia. Magadan: Institute for Biological Problems of the North. 253 p.

Mikhailov K.G. 2013. The spiders (Arachnida: Aranei) of Russia and adjacent countries a non-annotated checklist // Arthropoda Selecta. Supplement No 3. Moscow: KMK Scientific Press Ltd. $262 \mathrm{p}$.

Mikhailov K.G., Mikhailova E.A. 2002. Altitudinal and biotopic distribution of the spider family Gnaphosidae in North Ossetia (Caucasus Major) // Toft S., Scharff N. (eds.). European Arachnology 2000. Proc. 19th Eur. Coll. Arach. P.261-265.

Murphy J. 2007. Gnaphosid genera of the world. British Arachnological Society, St Neots, Cambs. Vol.1, p.i-xii, 1-92; vol.2. p.i-11, 605 pp.

Nuruyeva T.V., Guseinov E.F. 2011. [To the study of the spider fauna (Arachnida, Araneae) of coastal zone of Caspian Sea within Gobusan territory] // Zoologiya Ýnstitutunun eserlYri. Baký: Elm. Vol.29. P.448-455 [in Russian, with English and Azerbaijani summaries].

Ovtsharenko V.I. 1982. [A systematic list of the spider family Gnaphosidae (Aranei) of the European part of the USSR and the Caucasus] // Entomologicheskoye Obozreniye. Vol.61. No.4. P. 830-844 [in Russian, with English summary].

Ovtsharenko V.I., Platnick N.I., Song D.X. 1992. A review of the North Asian ground spiders of the genus Gnaphosa (Araneae, Gnaphosidae) // Bulletin of the American Museum of Natural History. Vol.212. P.1-88.

Platnick N.I., Baehr B. 2006. A revision of the Australasian ground spiders of the family Prodidomidae (Araneae, Gnaphosoidea) // Bulletin of the American Museum of Natural History. Vol.298. P.1-287

Platnick N.I., Murphy J.A. 1984. A revision of the spider genera Trachyzelotes and Urozelotes (Araneae, Gnaphosidae) // Ameri- 
can Museum Novitates. No.2792. P.1-30.

Tuneva T.K., Esyunin S.L. 2003. A review of the family Gnaphosidae in the fauna of the Urals (Aranei), 4. The first record of Gnaphosa tigrina Simon, 1878 and remarks on two species from the rufula group // Arthropoda Selecta. Vol.11 (for 2002). No.4. P.277-281.
Zamani A., Mirshamsi O., Rashidi P., Marusik Y.M., Moradmand M., Bolzern A. 2016. New data on the spider fauna of Iran (Arachnida: Aranei), part III // Arthropoda Selecta. Vol.25. No.1. P.99-114.

Responsible editor K.G. Mikhailov 